\title{
Public Capital and Asset Prices: \\ Time-series Evidence from Japan
}

\author{
Kazuki Hiraga \\ Masafumi Kozuka \\ Tomomi Miyazaki \\ September 2016 \\ Discussion Paper No.1625
}

GRADUATE SCHOOL OF ECONOMICS

KOBE UNIVERSITY

ROKKO, KOBE, JAPAN 


\title{
Public Capital and Asset Prices: Time-series Evidence from Japan
}

\author{
Kazuki Hiraga* \\ Masafumi Kozuka \\ Tomomi Miyazaki^
}

\begin{abstract}
This research examines the effects of public infrastructure capital on asset prices in Japan over the periods from 1983:Q1 to 2008:Q4. The empirical results show that while public infrastructure capital forecasts the stock price returns and total factor productivity by Granger's causality test after 1991, the contribution of public investment on stock returns is small by variance decomposition using FactorAugmented VAR model. Our empirical evidence on the post high-growth era in Japan suggest that although public capital forecasts stock price returns and TFP, public infrastructure investment is not expected to play a key role of revitalizing capital markets.
\end{abstract}

JEL classification: E44, G12, H54

Keywords: Public infrastructure capital in Japan; Stock price targeting; Lagaugmented VAR; Factor Augmented VAR;

\footnotetext{
- The authors would like to thank for Isaac Otchere for valuable comments and suggestions. This work has been financially supported by the Japan Society for the Promotion of Science (Grant-in-Aid for Scientific Research \# 26380361) and Financial Aid by Ishii Memorial Securities Research Promotion Foundation, Japan Securities Scholarship Foundation, and Yu-cho Foundation. Takuya Matsuyama and Koichi Watanabe are excellent research assistants. The usual disclaimer applies.

* Associate Professor, School of Political Science and Economics, Tokai University.

E-mail: khiraga581470@gmail.com

- Associate Professor, Faculty of Economics, University of Marketing and Distribution Sciences. Research Fellow, Graduate School of Economics, Kobe University.

E-mail: Masafumi_Kozuka@red.umds.ac.jp

^ Corresponding Author: Associate Professor, Graduate School of Economics, Kobe University. 2-1, Rokkodai-cho, Nada-ku, Kobe, Hyogo 657-8501, JAPAN. E-mail: miyazaki@econ.kobe-u.ac.jp
} 


\section{Introduction}

Emerging markets and developing economies (EMDE) have played an important role in international capital markets in recent years. For example, the IMF (2016) shows that spillovers of EMDE shocks to equity prices and exchange rates in advanced and emerging market economies explain over $30 \%$ of the variation in asset returns in these countries. On the other hand, some relatively developed countries in EMDE have invested large amounts of money in infrastructure investment, which has contributed to revitalizing their respective stock markets. For example, the Chinese government implemented a large economic stimulus package after the 2008 global financial crisis (GFC). About $80 \%$ of the package was spent on public infrastructure investment, and stock prices rose as a result despite the GFC. The Chinese example suggests that public infrastructure investment is useful for revitalization of the stock market as well as infrastructure development in EMDE.

This research examines the effects of public capital on asset prices in Japan. The government of Japan, which has aggressively implemented public infrastructure investment, has also implemented economic stimulus packages including public 
infrastructure investment to keep stock prices high. In other words, the policy for attaining both the revitalization of the stock market and infrastructure development through public infrastructure investment has been pursued in practice in Japan for a long period of time even before the GFC. Therefore, our empirical evidence on Japan may have implications for the revitalization of capital markets and public infrastructure investment policy in relatively developed countries in EMDE.

However, to our knowledge, no previous works have examined the effect of public capital on stock price returns in Japan. Many works such as those of Kitasaka (1998), Yoshino and Nakajima (1999), Nemoto et al. (1999), and Annala et al. (2008) have examined the macroeconomic effects of public infrastructure capital in Japan. However, these works have not examined the effects on stock market performance. Accordingly, our research fills a gap in the literature on Japanese public infrastructure investment policy and stock market revitalization.

To perform empirical investigation, we use both the standard VAR model and Toda and Yamamoto (1995)'s Lag-Augmented VAR (LA-VAR) for Granger's causality test, and implement variance decomposition using the Factor-Augmented VAR (FAVAR) model. 
The results show that while the null hypothesis of no Granger's causality from public capital to stock price returns and Total Factor Productivity (TFP) is rejected based on the test model over the periods of 1991:Q1-2007:Q4, the movement of public investment can only be a fraction of the movements of asset price returns using variance decomposition. Our empirical evidence from the era of post-high growth in Japan suggests that public infrastructure investment will not necessarily be useful for revitalization of the stock market.

This paper is organized as follows. Section 2 summarizes the public investment policy and stock price target policy in Japan. Section 3 presents a theoretical background and testable hypothesis. Section 4 reports the estimation results and discusses the implications for EMDE. Section 5 presents our conclusion.

\section{Background: Public infrastructure investment and stock target policy in}

\section{Japan}

Figure 1 shows the movement of public infrastructure investment (public capital 
formation, per GDP) among some developed countries. Public infrastructure investment had been highest among these groups until the mid-2000s, which shows that the Japanese government implemented a large amount of public infrastructure investment. A lot of public infrastructure was destroyed during World War II, which the government repaired in the decades after the end of the war. Moreover, since the lack of public infrastructure was a bottleneck for economic recovery, the government implemented large-scale infrastructure investment such as the construction of the Tokaido Shinkansen network and Keihin factory area. These public infrastructures, which were concentrated in three major metropolitan areas (Kanto, Chubu, and Kansai), supported the tremendous growth in the mid-1950s to the early 1970s in Japan.

On the other hand, public infrastructure investment has been frequently used as a tool of macroeconomic stabilization. ${ }^{1}$ Above all, after the collapse of the asset price bubbles in the early 1990s, the government implemented fiscal stimulus packages almost every year, as shown in Table 1. Stimulus packages implemented in August 1992, April 1993,

\footnotetext{
1 For more details, please see Miyazaki (2010) and Asako (2012).
} 
and September 1995 comprised more than half of public infrastructure investment. ${ }^{23}$

The Japanese government implemented these stimulus packages also as a tool for supporting stock prices in these periods. Actually, Fukuda and Yamada (2011) argue that stock prices were a target of Japanese macro stabilization policy during the 1990s. The government implemented stimulus packages that mostly consisted of public infrastructure investment to maintain stock prices in these periods. Following these, the Japanese case is worth investigating to examine the relationship between public infrastructure investment and stock prices.

\section{Theoretical background and our empirical strategies}

\subsection{Theoretical background}

Some theories explain that public infrastructure investment affects asset prices through two paths. One is the direct path, which means that public infrastructure

\footnotetext{
2 Whereas the Public Finance Act in Japan prohibits the issue of deficit bonds in principle, the Act allows limited bond issuance in the General Account (the Japanese central government's budget) to raise funds to finance public investments, equity investments, and loans to public corporations. Reflecting this, the government has mainly used public infrastructure investment as an economic stimulus by issuing construction bonds.

3 Incidentally, the Japanese government also implemented large economic stimulus packages after the economic slowdown accompanying the 2008 global financial crisis. However, the principal items in these packages were not public investment but subsidies or tax cuts such as lump sum transfers (teigaku-kyuhu kin), subsidies for consumer purchases of energy-conserving home appliances, and a program of tax breaks and subsidies for purchasing "eco-friendly" cars and financial support for small and medium-sized enterprises. For more details, see Iwaisako (2010) and Miyazaki (2016).
} 
investment affects asset prices directly. Fiscal policy is also expected to raise asset prices,

as examined in works by Agnello and Sousa (2011) and Nutahara (2013), which show that fiscal stimulus increases the aggregate demand and expected present value of profit (i.e. asset prices). This channel may also be applicable to public infrastructure investment, and we define this as the short-run effect of public infrastructure investment on stock prices.

The other is the indirect path: public capital stock increases the marginal productivity of private enterprises, and thereby, it raises asset prices. This is examined by both theoretical and empirical models in Belo and Yu (2013). Belo and Yu (2013) assume that public capital is one of the inputs in a firm's production technology and they assume that it also affects the marginal productivity of private inputs. ${ }^{4}$ Their theoretical model also shows that if public sector capital increases the marginal productivity of private inputs, there is a positive relationship between the public sector investment rate and the firm's risk premium. This can be defined as the long-term effect of public infrastructure capital (or stock effect) on stock prices.

\footnotetext{
${ }^{4}$ Detailed explanation is shown in Appendix 1.
} 


\subsection{Our empirical strategies and the variables used in estimation}

We follow two procedures to quantify the relationship between public infrastructure capital and stock prices. Firstly, we perform Granger's causality test to check whether public capital can be used to forecast future stock prices. Secondly, we check the contribution of the shocks of public investment policy on the fluctuation of stock prices through variance decomposition based on the estimation results by VAR. We capture the direct effect of public infrastructure investment (discussed in Section 3.1) by the shortrun observations of variance decomposition, and the indirect effect of public infrastructure capital stock (defined in Section 3.1) can be explained by the long-run observation of variance decomposition.

To implement variance decomposition, we take differences for public infrastructure capital data both for making the variable stationary and for capturing the shocks of public investment policy in the short-run. We use the FAVAR method because this enables us to purify the shocks of public investment policy by applying principal component analysis for the VAR model considering potential omitted variables as slow moving and fast moving. 
We use three variables in estimation: stock market returns $\left(R_{t}\right)$, TFP $\left(T F P_{t}\right)$, and government capital stock $\left(G_{t}\right)$. TFP is also added because public capital affects stock prices through the increase of private firm's productivity if indirect path shown above is also the case.

\section{Empirical Results}

\subsection{Dataset}

Data on stock price returns came from the data of stock price earnings ratio provided by Japan Securities Research Institute. TFP is made by us, and details are shown in Appendix 1. Public infrastructure capital data came from the data calculated by the Cabinet Office in Japan (accessed last May 21, 2016). Incidentally, the official data by the Cabinet Office in Japan offers only annual data. Therefore, we converted the original annual capital stock data into quarterly basis (initial value) data following the procedure employed by Kitasaka (1998); we did this using the weight for each quarter 
calculated by the real seasonally-adjusted general government gross capital formation

data. ${ }^{5}$

The Cabinet Office made public infrastructure capital stock data by considering four

types of depreciation; straight-line method, declining-balance method, and the two

types of depreciation shown in the method of the OECD (2009). ${ }^{6}$ We use all data made

by considering different types of depreciation. "G1" is the data made by the straight-

line method, "G2" is made by the declining-balance method, and the stock data named

"G3a" and "G3b" follow the method of the OECD (2009).

In the straight-line method, which is employed in "G1," a fixed value of depreciation is

appropriated every year through the durable periods of fixed assets.

The decline-balance method, which is utilized in "G2," is a way of appropriating the

depreciation amount considering a fixed rate of depreciation through the durable

periods. Here, the non-depreciated balance at the beginning of each period is multiplied

by the constant depreciation rate. ${ }^{7}$

${ }^{5}$ For more details, please see Kitasaka (1998).

${ }^{6}$ For more details, please see http://www5.cao.go.jp/keizai2/jmcs/jmcs.html .

${ }^{7}$ In previous studies about consumption on durable goods, they calculate the service flow of durable goods expenditure with similar method to decline-balance method. 
In the OECD (2009) method, used in "G3a" and G3b," the decrease in efficiency of public

capital caused by, for example, physical depreciation and obsolescence, is considered. In

this method, firstly, the pattern of decline in value of services brought by public capital

in the future is assumed. Then, the discount rate is set up based on the assumed decline

in value, and the present discount value of services obtained by public capital is

calculated.

When the pattern of decline in value in the first step is set up, two kinds of estimation

can be utilized; estimation with linear function and with hyperbolic function. For "G3a,"

linear function is utilized. And for "G3b," hyperbolic function is employed.

We assume that public infrastructure investment is a public good in that a public

infrastructure is a non-excludable good, which potentially affects the economic

activities of all industries. Thus, we did not divide the public infrastructure into sectors

such as roads, educational facilities, and sewers. ${ }^{8}$

The sample period is from the first quarter of 1983 to the fourth quarter of 2008.

\footnotetext{
8 Just to make sure, we also estimate the model by limiting the category of infrastructure sock into the industrial infrastructures such as road, port, airport, and water sewage for productions. However, the results are not so drastically changed from our reported results. Details can be available from the author's website: https://sites.google.com/site/tomomisite/research/dp .
} 


\subsection{Results of unit-root tests and Granger's causality test}

Firstly, we report the results of the unit-root tests. To check whether each variable is stationary, we use the Augmented Dickey-Fuller (1979) (ADF) test.

Table 2 shows the results for the variables used in the estimation. The table reports that the level of $R_{t}$ is stationary for both cases, the levels of $T F P_{t}$ and $G_{t}$ are nonstationary especially in the case of a constant term with trend. Hence, we need to test the first differences of the series. All tests strongly reject the null hypothesis of nonstationarity for the first differences. Therefore, all variables may be treated as a single (I (1)) unit-root process.

Secondly, we check the optimal length of lags. Following the likelihood ratio test of Sims (1980), the optimal length of lags of the three-variable VAR model is 4 for all cases.

Thirdly, we explain Granger's causality test. To implement this, we employ the LA-

VAR model as well as the VAR model taking first differences. Following LA-VAR model, we can also estimate the VAR model with the level of variables without considering the degree of integration or the existence of a cointegration relationship. When the optimal 
lag is $\mathrm{n}$ and the integrated order of included variables is at most $\mathrm{d}$, we set the length of lags of the VAR model to be $n+d$. Our degree of integration is at most one following the unit-root tests, and our optimal lag length is four based on the likelihood ratio test. Thus, we set the lag length of the VAR model taking first differences (standard VAR) as four, and the one of LA-VAR (LA-VAR) as five, respectively.

Before we implement the VAR estimation, we check the structural change. Figure 2 reports the movement of stock price returns. According to this figure, stock price returns were volatile from the late 1980s to the early 1990s. These periods are equivalent to the asset price bubble periods in Japan. Actually, following Christiano (1986) and Cecchetti and Karras (1994), we note a structural change in the data after this quarter. ${ }^{9}$ Furthermore, after 2008, the volatility of stock price returns was large owing to the collapse of Lehman. Thus, we also estimate the model using the sample periods over the 1991:Q1 to 2007:Q4. Here the lag length is set as four for standard VAR and five for LAVAR, respectively.

9 Detailed results can be obtained from the authors upon request. 
Table 3 reports the results of Granger's causality test for all our sample periods.

Although the null hypothesis that TFP does not Granger-cause R is strongly rejected, the null that $\mathrm{G}$ does not Granger-cause $\mathrm{R}$ is accepted for all cases. In addition, we limit the sample periods from 1991:Q1 to 2007:Q4. Here we also confirm that TFP can forecast future stock returns. Furthermore, we can reject the null that G does not Granger-cause $\mathrm{R}$ for the standard VAR model and the LA-VAR model.

The results obtained by Granger's causality test show that public capital affected stock price returns after the collapse of the asset price bubbles at the beginning of the 1990s. Moreover, we confirm that public capital can forecast TFP, and TFP affects stock price returns. As shown in Section 3, public infrastructure indirectly affects stock prices through the increase in the productivity of the private sector. Both direct and indirect effects of public infrastructure investment might be implied following the results of Granger's causality test.

\subsection{Results of variance decomposition}

We obtain the results as the variance decompositions of each stock return with respect 
to the contribution of a public investment shock, shown in Table $5 \mathrm{a}^{-} 5 \mathrm{~d}^{10}$. We estimate

factors from a dataset, which containing 28 industries quarterly macroeconomic time

series (public capital, total factor productivity (TFP) and stock price return of aggregate

and sectoral data), for 1991:Q1 to 2007:Q4, when the null that G does not Granger-cause

$\mathrm{R}$ can be rejected.11 Similar to Bernanke et al. (2005), we take a logarithm difference of

TFP. In our setting, fast-moving variable is TFP and slow-moving variables are

aggregate and sectoral stock price returns. ${ }^{12}$

The estimation results show that the medium- and long-term effects of public

infrastructure investment are relatively larger than the short-term effect in any industry.

This result implies that the supply-side effect may be dominant. On the other hand, the

absolute impact is not so large. That is, the contribution of public infrastructure

investment shocks can explain only a fraction of the fluctuation of stock price returns.

10 Following the criteria of Bai and $\mathrm{Ng}$ (2002), we set three factors (i.e. $\mathrm{K}=3$ ).

11 There are stock returns of Aggregate, Agriculture, Mining, Construction, Food, Fiber, Pulp and Paper (Paper), Chemical, Petro-Coal (Petro), Rubber, Glass, Steel, Non-steel, Metal, Machine, Electrical equipment, Transportation machine, Precision mechanical, Other machine, Commerce, Finance, Real estate, Land transport, Shipping, Air transport, Warehousing, Information, Utility, Service industries.

12 TFP is still aggregate level data even when we conduct an investigation using sectoral data.

Sectoral GDP annual data are presented because we cannot acquire such data on a quarterly basis. Therefore, we use aggregate TFP data even for the exercises using sectoral stock price returns. 


\subsection{Implications for EMDE}

Our empirical results after the 1990s in Japan show that whereas public infrastructure investment forecasts future stock price returns and TFP, the contribution of the shocks of the change in public infrastructure, or the shocks of public investment policy explain a fraction of the stock price returns.

The level of public capital in Japan has accumulated, reflecting the large amount of public investment, and Yoshino and Nakajima (1999) show that the marginal productivity of public capital in Japan after the 1970s is lower than that before the 1970s on a national level. Our results obtained by variance decomposition that quantitative contributions of public investment on stock price returns are small may be related to the low productivity of public capital.

EMDE shares a half of global infrastructure spending, according to Oxford Economics (2015). This also implies that the level of public capital in these relatively developed countries may sufficiently accumulate in the near future as a result of huge amount of infrastructure investment. If so, marginal productivity of public capital becomes low, and thus the effects on stock prices may not be as substantial as in the case of our results 
on variance decomposition. Our empirical evidence from the era of moderate growth in Japan suggests that in the near future, even if the governments in relatively developed countries among EMDE plan the public infrastructure investment in order to pursue the infrastructure development and the revitalization of the stock market, public infrastructure investment will not necessarily be useful.

\section{Conclusion}

This research examines the effects of public infrastructure capital on stock prices in Japan using Granger's causality test and variance decomposition calculated by FA-VAR.

Our results show that whereas public capital forecasts future stock price returns and TFP for the periods over 1991:Q1-2007:Q4, no industry can obtain a substantial recovery of stock price return on public investment stimulus from variance decomposition.

In future, we could also examine the effects of using firm-level data so as to compare the effects among more disaggregate industries as in the case of Nekarda and Ramey (2011). 
Appendix 1. Theoretical explanation of supply-side effect of public capital on stock return

This appendix introduces public sector physical capital into the neoclassical q-theory

model of investment following Belo and Yu (2013).

A.1. The setups

Firm technology is shown as follows:

$$
Y_{t}=e^{x_{t}}\left(G K_{t}\right)^{\alpha} K_{t},
$$

where $\mathrm{Y}$ is output, GK is public sector physical capital, $\mathrm{K}$ is private capital $\mathrm{xt}_{\mathrm{t}}$ is profitability shock_(or productivity shock). Seminal parameter $\alpha$ is the productivity (profitability) of public sector capital.

The accumulation processes of private and effective public capital are shown as Eq.

(A.2) and (A.3):

$$
K_{t+1}=(1-\delta) K_{t}+I_{t},
$$




$$
G K_{t+1}=\left(1-\delta^{G K}\right) G K_{t}+G I K_{t}
$$

where $G I K_{t} \equiv G I_{t} / \widetilde{G K}_{t}$ is the public sector investment rate, $G I_{t}$ is the total investment in public sector capital, $\widetilde{G K}_{t}$ is the total stock of public sector capital and $\delta^{G K}$ is the depreciation rate. The specification of Eq. (A.3) guarantees that the stock of effective public sector capital is stationary ${ }^{13}$, the adjustment cost of private capital

$$
g\left(I_{t}, K_{t}\right)=\frac{c}{2}\left(I K_{t}\right)^{2} K_{t}
$$

where $I K_{t} \equiv I_{t} / K_{t}$ is the private sector investment rate.

A.2. The firm's maximization problem

Suppose that the firm is all-equity financed. Dividends $D_{t}$ distributed by the firm to the shareholders are given by:

13 Assumption of stationary is necessary condition to derive the empirical predictions as effective stock of public sector capital is equal to detrended stock of total public capital. 


$$
D_{t}=e^{x_{t}}\left(G K_{t}\right)^{\alpha} K_{t}-I_{t}-\frac{c}{2}\left(I K_{t}\right)^{2} K_{t}
$$

The cumulative dividend market value $V^{C U M}\left(s_{t}\right)$ is shown as follows:

$$
V^{C U M}\left(s_{t}\right)=\max _{l_{t+j}, K_{t+j+1}}\left\{E_{t}\left[\sum_{j=0}^{\infty} M_{t, t+j} D_{t+j}\right]\right\},
$$

Subject to Eq. (A.2) and (A.3) for all dates t. $s_{t}=\left(K_{t}, G K_{t}, G I K_{t}, x_{t}\right)$ is the vector of state variables and $M_{t, t+j}$ is a market -determined stochastic discount factor at period $t$, which is used to value the cash flows arriving in period $t+j$.

\section{A.3. First-order conditions}

We solve the maximization problem of Eq. (A.6). First order conditions with respect to

$l_{t}$ and $K_{t+1}$ are as follows:

$$
q_{t}=1+c \cdot I K_{t}
$$




$$
q_{t}=E_{t}\left[M_{t, t+1}\left(e^{x_{t+1}}\left(G K_{t+1}\right)^{\alpha}+\frac{2}{c}\left(I K_{t}\right)^{2}+(1-\delta)\left(1+c \cdot I K_{t}\right)\right)\right]
$$

Combining Eq. (A.2), (A.3), (A.7), (A.8) and the standard asset pricing equation $E_{t}\left[M_{t, t+1} R_{t+1}^{l}\right]=1$, in which $R_{t+1}^{l}$ is the private sector investment return, we obtain $R_{t+1}^{l}$ as follows:

$$
R_{t+1}^{l} \equiv \frac{e^{x_{t+1}}\left(\left(1-\delta^{G K}\right) G K_{t}+G I K_{t}\right)^{\alpha}+2 / c \cdot\left(I K_{t+1}\right)^{2}+(1-\delta)\left(1+c \cdot I K_{t+1}\right)}{1+c \cdot I K_{t}}
$$

Equation (A.9) explains the supply-side effect of public capital shown in the first term of the numerator. If $\alpha$ is positive, stock return increases by a channel of positive production externality of public capital.

\section{Appendix 2. Calculation of potential GDP}

In order to obtain the Total Factor Productivity (TFP) in Japan, we have to calculate the Solow residual without measurement error. In this study, we employ the production 
function approach. The Economic Planning Agency (2000) and Kamamta and Masuda (2001) calculate the Solow residual derived from Cobb=Douglas type production functions. Here, we follow the methods shown in Kamamta and Masuda (2001). Figure A.1. offers the source of the data.

Firstly, we set the real GDP as $Y_{t}$, capital stock as $K_{t}$, total labor hours (working population $\times$ working hours) as $L_{t}$, Solow residual as $A_{t}$, the operating ratio of capital as $\lambda$, and the coefficient labor input as $\alpha$. The parameter $\alpha$ is defined as "Compensation of employees $\div$ total income" supposing the perfect competition. Then, the production function is

$$
\ln Y_{t}=\ln \bar{A}_{t}+(1-\alpha) \ln \lambda K_{t}+\alpha \ln L_{t} .
$$

The real GDP and the capital stock are 68SNA in the Annual Report on National Accounts. The industry consists of manufacturing and non- manufacturing sectors, and $\ln \lambda K_{t}$ can be written as 


$$
\ln \lambda K_{t}=\ln \left(\lambda_{m} K_{m t}+\lambda_{n m} K_{n m t}\right)
$$

Here, $m$ indicates the manufacturing and $\mathrm{nm}$ the non- manufacturing industry. We must consider the $\lambda_{n m}$ because we cannot obtain the Japanese data. Previous studies assumed that the operating ratio of non-manufacturing is always $100 \%$, and the measurement error remains in the Solow residual $\left(\ln A_{t}\right)$. In order to calculate TFP correctly, Kamata and Masuda (2001) use the Business Survey Index (BSI) of nonmanufacturing ${ }^{14}$.However, the BSI can be utilized from the second quarter of 1983 (hereafter 1983:2). On the other hand, the sample period is 1978 through 1997 in our study, and we must consider another method to obtain the operating ratio of the nonmanufacturing industry before 1983:2. Here, we obtain the average of two indices of manufacturing (operating ratio and IIP, indices of industrial production). We employ this proxy from 1978:Q3 to 1983:Q1, BSI from 1983:Q2 and connect them.

The Solow residual $\left(\ln \bar{A}_{t}\right)$ is calculated as follows:

14 In Kamata and Masuda (2001), the consumption of electric power is also considered to calculate the rate of operation. 


$$
\ln \bar{A}_{t}=\ln Y_{t}-(1-\alpha) \ln \lambda K_{t}-\alpha \ln L_{t}
$$

Here, we regard the Solow residual as the TFP.

\section{Appendix 3. Explanation of the FAVAR Model}

Appendix 2 explains the econometric framework for the FAVAR model. ${ }^{15}$ Let $Y_{t}$ be an $M \times 1$ vector of observable economic variables, where $M$ is small. Although $Y_{t}$ is used in a standard VAR, $Y_{t}$ alone does not easily add economic information. We therefore assume that a $K \times 1$ vector of unobserved factors, where $K$ is small, summarizes this additional information. The joint dynamics of $\left(F_{t}, Y_{t}\right)$ are given by

$$
\left[\begin{array}{l}
F_{t} \\
Y_{t}
\end{array}\right]=\Phi(L)\left[\begin{array}{l}
F_{t-1} \\
Y_{t-1}
\end{array}\right]+u_{t},
$$

where $\Phi(L)$ is a matrix of polynomials of finite order $d$ and the error term $u_{t}$ is the

mean 0 with covariance matrix $\Sigma$.

There is apparently little difference between a standard VAR and the FAVAR. Yet

15 This section conforms to Bernanke et al. (2005). For details, see Bernanke et al. (2005). 
Equation (A.13), which is a FAVAR, cannot be estimated because the factors are unobservable. We must therefore assume that the factors affect a large number of variables to estimate Equation (A.14). This assumption allows us to infer the unobservable factors from these economic time series variables. Let $X_{t}$ be an $N \times 1$ vector of informational economic variables, where $N$ is large, such that $K+M \ll N .16$ Also, assume that $X_{t}$ is related to both the unobservable factors vector $F_{t}$ and the observable factors vector $Y_{t}$, given as follows:

$$
X_{t}=\Lambda^{f} F_{t}+\Lambda^{y} Y_{t}+e_{t}
$$

where $\Lambda^{f}, \Lambda^{y}$ are the $N \times K, N \times M$ matrix of factor loadings, respectively, and $e_{t}$ is an $N \times 1$ vector of error terms, which is weakly correlated with the mean 0 .

For the estimation, we follow the two-step approach proposed by Bernanke et al. (2005). ${ }^{17}$ This means we identify $F_{t}$ in the first step and estimate Equation (A.13) in the

16 As Bernanke et al. (2005) point out, it is acceptable for $N$ to be greater than $T$.

17 Although Bernanke et al. (2005) estimate the FAVAR by the two-step approach and a Bayesian method based on Gibbs sampling, they suggest that the two-step approach tends to produce more plausible responses. 
second. Specifically, we perform the following procedures in the first step. Initially, the common components, $C_{t}$, are estimated using the first $K+M$ principal components of $X_{t}$. In the second step, following Bernanke et al. (2005), variables are classified as slow moving and fast moving. Slow-moving variables are those predetermined in the current period, such as output and employment. Fast-moving variables are those sensitive to contemporaneous economic news or shocks, such as asset prices. Next, a principal component analysis is applied to the slow-moving variables to derive a vector of slowmoving factors, $F_{t}^{S}$. Finally, the following regression is estimated:

$$
\hat{C}_{t}=b_{F^{S}} \hat{F}_{t}^{S}+b_{Y} Y_{t}+e_{t},
$$

where the estimated factors, $\hat{F}_{t}$, are obtained from $\hat{C}_{t}-b_{Y} Y_{t}$. In the second stage, we estimate the VAR in $\hat{F}_{t}$ and $Y_{t}$, and compute the impulse response function using a Choleski decomposition. 


\section{References}

Agnello, L., and R. M. Sousa. (2011) "Fiscal policy and asset prices." Bulletin of Economic Research 65:2, 154-177.

Annala, C. N., R. G. Batina, and J. P. Freehan. 2008. "Empirical Impact of Public Infrastructure Investment on the Japanese Economy." Japanese Economic Review 59: 419-437.

Asako, K. (2012) Studies on the Japanese Business Cycle. Tokyo: Maruzen Publishing.

Bai, J., and S. Ng. (2002) "Determining the number of factors in approximate factor models." Econometrica 70:1, 191-221.

Belo, F., and J. Yu. (2013) "Government investment and the stock market." Journal of Monetary Economics 60:3, 325-339.

Bernanke, B. S., J. Boivin., and P. Eliasz. (2005) "Measuring the effects of monetary policy: A factor-augmented Vector Autoregressive (FAVAR) approach.” Quarterly Journal of Economics 120:1, 387-422. 
Brückner, M., and A. Tuladhar. (2014) "Local government spending multipliers and

financial distress: Evidence from Japanese prefectures.” Economic Journal, 124:581,

1279-1316.

Cecchetti, S. G., and G. Karras. (1994) "Sources of output fluctuations during the

interwar period: further evidence on the causes of the Great Depression." Review of

Economics and Statistics, 76:1, 80-102.

Christiano, L. J. (1986) "Money and the U.S. economy in the 1980s: A break from the past?" Federal Reserve Bank of Minneapolis Quarterly Review Summer, 2-13.

Dickey, D. A., and A. Fuller. (1979) "Distribution of the estimators for autoregressive time series with a unit root." Journal of American Statistical Association 74:366, 427431.

Doi, T., and T. Ihori. (2009) The Public Sector in Japan. Cheltenham: Edward Elgar Publishing.

Economic Planning Agency, Keizai Hakusho Fiscal 2000 (Economic Survey of Japan Fiscal 2000: The New Era Begins), 2000 (in Japanese). 
Fukuda, S., and J. Yamada. (2011) "Stock price targeting and fiscal deficit in Japan: Why did the fiscal deficit increase during Japan's lost decades?" Journal of the Japanese and International Economies 25:4, 447-464.

IMF, 2016. Global Financial Stability Report.

http://www.imf.org/external/pubs/ft/survey/so/2016/POL040416B.htm

Iwaisako, T. (2010) "Japanese macroeconomic policy management after the global financial crisis." Public Policy Review 6, 795-806.

Kamada, K., and K. Masuda. (2001) "Effects of measurement error on the output gap in Japan,” Monetary and Economic Studies 19:2, 109-154.

Kisataka, S. (1999) "Optimality of Public Capital Supply: Examination by Euler Equation," JCER Economic Journal 39, 76-96 (in Japanese).

Miyazaki, T. (2010) "The effects of fiscal policy in the 1990s in Japan: A VAR analysis with event studies." Japan and the World Economy 22:2, 80-87.

Miyazaki, T. (2016) "Fiscal policy effectiveness in Japan: Evidence from recent policies." Applied Economics 48:27, 2506-2515. 
Nekarda, C. J., and V. A. Ramey., (2011) "Industry evidence on the effects of government spending." American Economic Journal: Macroeconomics 3, pp.36-59.

Nemoto, J., K. Kamada., and K. Kawamura. (1999) "Estimates of optimal public capital stocks in Japan: Using a public investment discount rate framework.” Empirical Economics 24:4, 693-710.

Nutahara, K., (2013) “Asset price targeting government spending and equilibrium indeterminacy in a sticky-price economy." CIGS Working Paper Series No. 13-003E.

Oxford Economics. (2015) Capital Project and Infrastructure Spending Outlook to 2025. http://www.pwc.com/cpi-outlook2025

Sims, A. C. (1980) "Macroeconomics and reality." Econometrica, 48:1, 1-48.

Toda, H. Y., and T. Yamamoto. (1995) "Statistical inference in vector autoregressions with possibly integrated processes.” Journal of Econometrics 66 (1-2): 225-250.

Yoshino, N., and N. Nakajima eds. (1999) Economic Effects of Public Investment.

Tokyo: Nihon-hyoron-sha (in Japanese). 
Figure 1. Government gross capital formation per GDP among some developed countries

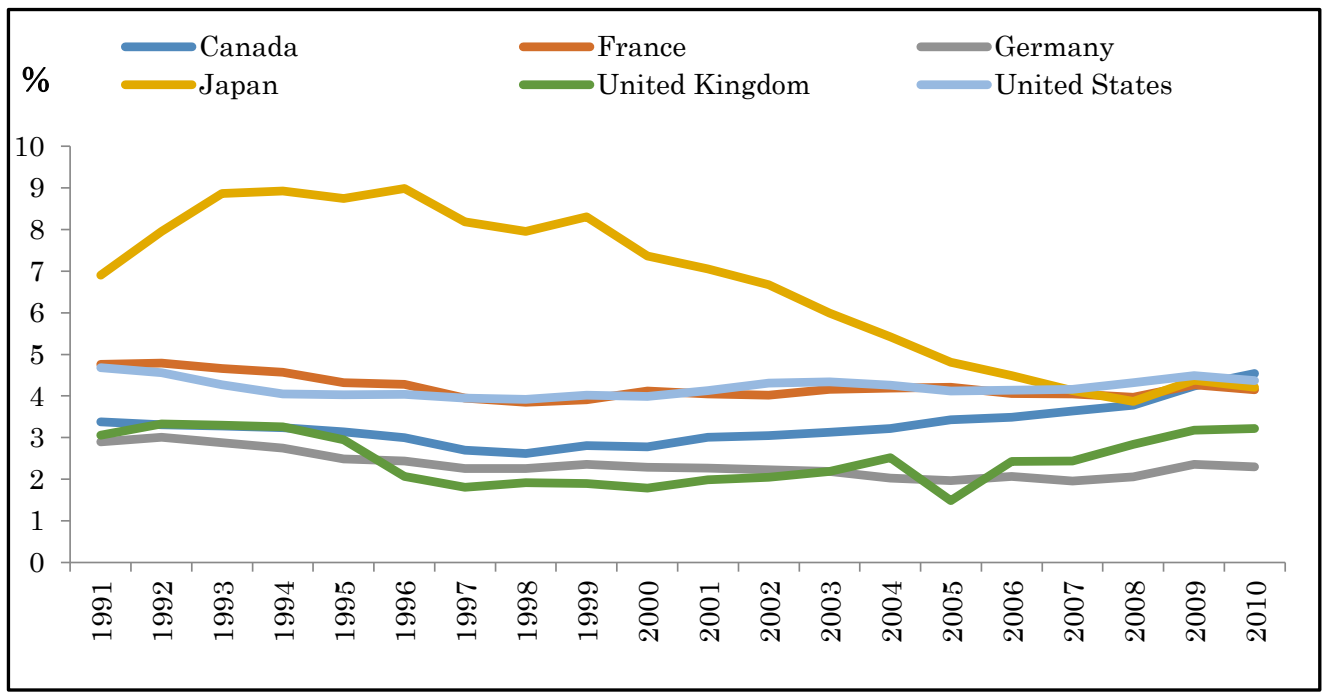

Source: OECD Economic Outlook

Figure 2. The movement of stock price returns

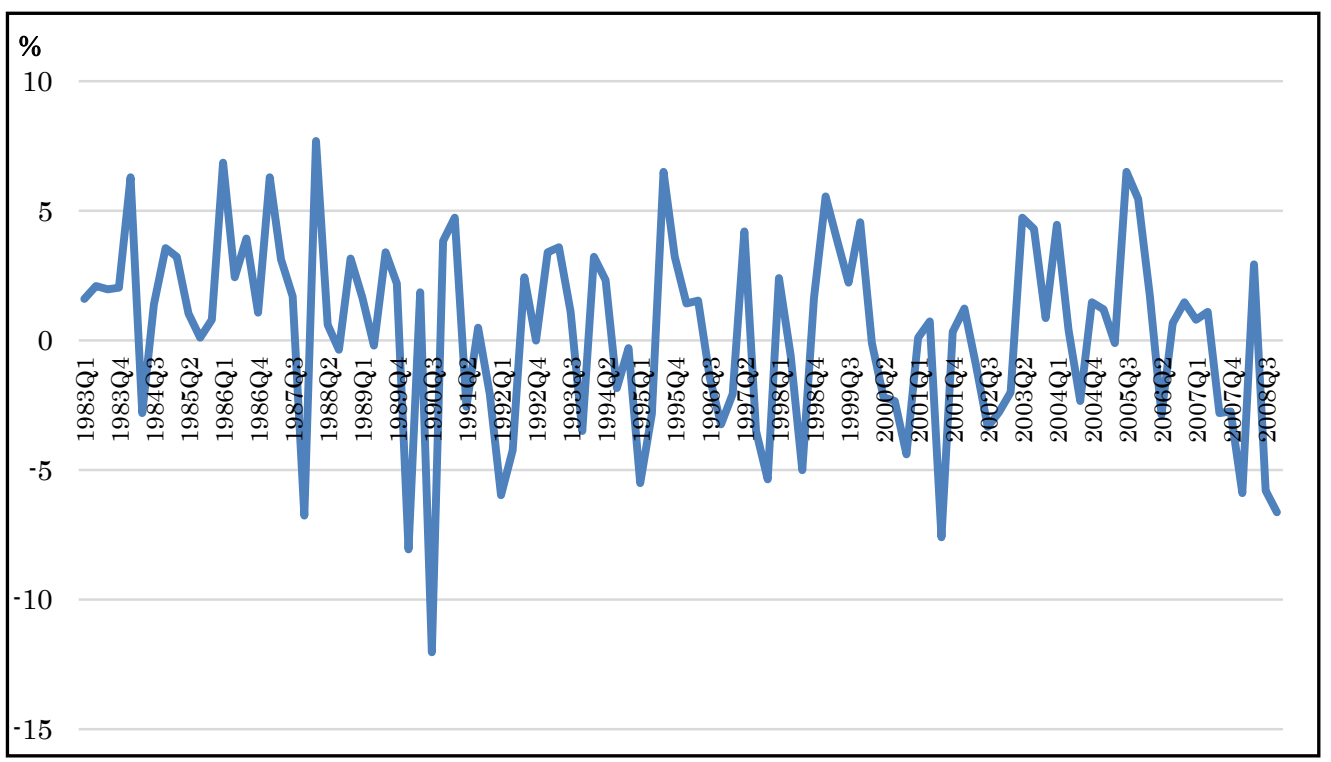


Table 1. Fiscal Stimulus Packages in the 1990s (JPY trillion)

\begin{tabular}{|c|c|c|c|c|c|c|c|c|c|c|}
\hline & $\begin{array}{c}1992 \\
\text { August }\end{array}$ & $\begin{array}{l}1993 \\
\text { April }\end{array}$ & September & $\begin{array}{c}1994 \\
\text { Februrary }\end{array}$ & $\begin{array}{l}1995 \\
\text { April }\end{array}$ & September & $\begin{array}{l}1998 \\
\text { April }\end{array}$ & November & $\begin{array}{c}1999 \\
\text { November }\end{array}$ & $\begin{array}{c}2000 \\
\text { October }\end{array}$ \\
\hline Tax cut & & 0.2 & & 5.9 & & & 4.6 & 6 & & \\
\hline $\begin{array}{c}\text { Cash transfers } \\
\text { to housholds }\end{array}$ & & & & & & & & 0.7 & & \\
\hline $\begin{array}{c}\text { Public works } \\
\text { (Public } \\
\text { investment) }\end{array}$ & 6.3 & 7.2 & 2 & 3.7 & 0 & 7.7 & 3.1 & 3.6 & 2.9 & 2.6 \\
\hline $\begin{array}{l}\text { Public works } \\
\text { involving central } \\
\text { government }\end{array}$ & 4.5 & 5.6 & 1.5 & 3.4 & & 6.7 & 1.6 & 3.6 & 2.9 & 2.6 \\
\hline $\begin{array}{l}\text { Public works by } \\
\text { local } \\
\text { governments }\end{array}$ & 1.8 & 1.6 & 5 & 0.3 & & 1 & 1.5 & & & \\
\hline $\begin{array}{l}\text { Other } \\
\text { government } \\
\text { investment }\end{array}$ & & & & & 5.4 & 1.4 & 4.6 & 3.6 & 4 & 2.6 \\
\hline $\begin{array}{l}\text { Other } \\
\text { government } \\
\text { measures }\end{array}$ & 4.5 & 5.8 & 4 & 5.7 & 1.5 & 5.2 & 4.4 & 9.1 & 11.3 & 5.8 \\
\hline $\begin{array}{l}\text { Total size of } \\
\text { economic } \\
\text { stimulus } \\
\text { packages }\end{array}$ & 10.8 & 13.2 & 6 & 15.3 & 6.9 & 14.3 & 16.7 & 23 & 18.2 & 11 \\
\hline
\end{tabular}

Note: This table follows Brückner and Tuladhar (2014). Other government investment includes investment in fields such as science and technology, education and social welfare, alternative energy and the environment, and natural disaster relief. All government investment in economic stimulus packages in April 1995 was for natural disaster relief because this package was planned as a countermeasure for the Great Hanshin-Awaji earthquake.

Table 2. Results of unit-root tests

\begin{tabular}{|c|c|c|c|c|c|c|}
\hline $\begin{array}{l}\text { ADF test } \\
\langle\text { Level }\rangle\end{array}$ & & & & & & \\
\hline Variable & with const. & & & with const. & nd tren & \\
\hline & Test stat. & Lags & & Test stat. & Lags & \\
\hline $\mathrm{R}$ & -8.971 & 0 & **** & -9.255 & 0 & $* * *$ \\
\hline TFP & -3.395 & 4 & $* *$ & -1.176 & 4 & \\
\hline G1 & -2.569 & 4 & & -0.387 & 4 & \\
\hline G2 & -2.498 & 4 & & -0.182 & 4 & \\
\hline G3a & -2.651 & 4 & & -0.158 & 4 & \\
\hline G3b & -2.584 & 4 & & -0.400 & 4 & \\
\hline \multicolumn{7}{|c|}{$\langle 1$ st difference $\rangle$} \\
\hline \multirow[t]{2}{*}{ Variable } & with const. & & & \multicolumn{3}{|c|}{ with const. and trend } \\
\hline & Test stat. & Lags & & Test stat. & Lags & \\
\hline $\mathrm{R}$ & -8.016 & 4 & **** & -7.991 & 4 & *** \\
\hline TFP & -4.145 & 4 & $* * *$ & -6.958 & 3 & $* * *$ \\
\hline G1 & -6.900 & 4 & $* * *$ & -7.602 & 4 & $* * *$ \\
\hline G2 & -5.360 & 3 & $* * *$ & -6.815 & 4 & $* * *$ \\
\hline G3a & -6.775 & 4 & *** & -7.500 & 4 & $* * *$ \\
\hline G3b & -6.900 & 4 & $* * *$ & -7.611 & 4 & $* * *$ \\
\hline
\end{tabular}

$<$ Note $>$ The lag length is chosen using the AIC by setting the maximum length as

four. Levls of significance: $* *=5 \%$ and $* * *=1 \%$. 
Table 3. Results of Granger's causality test (Sample periods: 1983:Q1-2008:Q4)

\begin{tabular}{|c|c|c|c|}
\hline \\
\hline & Null Hypothesis: & Wald-Statistics & Prob. \\
\hline & G does not Granger-cause $R$ & 7.614 & \\
\hline \multirow[t]{3}{*}{$\mathrm{G}=\mathrm{G} 1$} & G does not Granger-cause TFP & 30.998 & $* * *$ \\
\hline & TFP does not Granger-cause R & 7.014 & \\
\hline & G does not Granger-cause $R$ & 7.674 & \\
\hline \multirow[t]{3}{*}{$\mathrm{G}=\mathrm{G} 2$} & G does not Granger-cause TFP & 30.972 & *** \\
\hline & TFP does not Granger-cause $R$ & 7.029 & \\
\hline & G does not Granger-cause $R$ & 7.675 & \\
\hline \multirow[t]{2}{*}{$\mathrm{G}=\mathrm{G} 3 \mathrm{a}$} & G does not Granger-cause TFP & 31.075 & $* * *$ \\
\hline & TFP does not Granger-cause $R$ & 7.022 & \\
\hline & G does not Granger-cause $R$ & 7.609 & \\
\hline \multirow[t]{2}{*}{$\mathrm{G}=\mathrm{G} 3 \mathrm{~b}$} & G does not Granger-cause TFP & 31.016 & *** \\
\hline & TFP does not Granger-cause R & 7.012 & \\
\hline \multicolumn{4}{|c|}{ LA-VAR } \\
\hline & Null Hypothesis: & Wald-Statistics & Prob. \\
\hline & G does not Granger-cause R & 5.546 & \\
\hline \multirow[t]{3}{*}{$\mathrm{G}=\mathrm{G} 1$} & G does not Granger-cause TFP & 28.896 & $* * *$ \\
\hline & TFP does not Granger-cause $\mathrm{R}$ & 7.602 & \\
\hline & G does not Granger-cause $R$ & 5.635 & \\
\hline \multirow[t]{3}{*}{$\mathrm{G}=\mathrm{G} 2$} & G does not Granger-cause TFP & 28.769 & *** \\
\hline & TFP does not Granger-cause $R$ & 7.824 & \\
\hline & G does not Granger-cause R & 5.679 & \\
\hline \multirow[t]{3}{*}{$\mathrm{G}=\mathrm{G} 3 \mathrm{a}$} & G does not Granger-cause TFP & 28.852 & *** \\
\hline & TFP does not Granger-cause R & 7.825 & \\
\hline & G does not Granger-cause $R$ & 5.541 & \\
\hline \multirow[t]{2}{*}{$\mathrm{G}=\mathrm{G} 3 \mathrm{~b}$} & G does not Granger-cause TFP & 28.917 & $* * *$ \\
\hline & TFP does not Granger-cause $R$ & 7.583 & \\
\hline
\end{tabular}

$<$ Note $>$ Wald statistics obey $\chi \uparrow 2$ distribution with $D F=4$.

Critical values are $13.280(1 \%$ level, $* * *), 9.490(5 \%, * *)$ and $7.780(10 \%$ level, $*)$. 
Table 4. Results of Granger's causality test (Sample periods: 1991:Q1-2007:Q4)

Standard Granger Causality

\begin{tabular}{|c|c|c|c|}
\hline & Null Hypothesis: & Wald-Statistics & Prob. \\
\hline & G does not Granger-cause R & 11.724 & $* *$ \\
\hline \multirow[t]{3}{*}{$\mathrm{G}=\mathrm{G} 1$} & G does not Granger-cause TFP & 15.808 & $* * *$ \\
\hline & TFP does not Granger-cause R & 15.519 & $* * *$ \\
\hline & G does not Granger-cause R & 11.773 & $* *$ \\
\hline \multirow[t]{3}{*}{$\mathrm{G}=\mathrm{G} 2$} & G does not Granger-cause TFP & 15.867 & $* * *$ \\
\hline & TFP does not Granger-cause R & 19.545 & $* * *$ \\
\hline & G does not Granger-cause R & 11.778 & $* *$ \\
\hline \multirow[t]{3}{*}{$\mathrm{G}=\mathrm{G} 3 \mathrm{a}$} & G does not Granger-cause TFP & 15.896 & $* * *$ \\
\hline & TFP does not Granger-cause R & 19.554 & *** \\
\hline & G does not Granger-cause R & 11.778 & $* *$ \\
\hline \multirow[t]{2}{*}{$\mathrm{G}=\mathrm{G} 3 \mathrm{~b}$} & G does not Granger-cause TFP & 15.896 & $* * *$ \\
\hline & TFP does not Granger-cause R & 19.554 & $* * *$ \\
\hline \multicolumn{4}{|c|}{ LA-VAR } \\
\hline & Null Hypothesis: & Wald-Statistics & Prob. \\
\hline & G does not Granger-cause $R$ & 10.832 & $* *$ \\
\hline \multirow[t]{3}{*}{$\mathrm{G}=\mathrm{G} 1$} & G does not Granger-cause TFP & 17.483 & $* * *$ \\
\hline & TFP does not Granger-cause R & 19.467 & $* * *$ \\
\hline & G does not Granger-cause R & 10.891 & $* *$ \\
\hline \multirow[t]{3}{*}{$\mathrm{G}=\mathrm{G} 2$} & G does not Granger-cause TFP & 17.562 & $* * *$ \\
\hline & TFP does not Granger-cause R & 19.624 & $* * *$ \\
\hline & G does not Granger-cause R & 10.923 & $* *$ \\
\hline \multirow[t]{3}{*}{$\mathrm{G}=\mathrm{G} 3 \mathrm{a}$} & G does not Granger-cause TFP & 17.637 & $* * *$ \\
\hline & TFP does not Granger-cause R & 19.689 & $* * *$ \\
\hline & G does not Granger-cause R & 10.832 & $* *$ \\
\hline \multirow[t]{2}{*}{$\mathrm{G}=\mathrm{G} 3 \mathrm{~b}$} & G does not Granger-cause TFP & 17.483 & $* * *$ \\
\hline & TFP does not Granger-cause R & 19.462 & $* * *$ \\
\hline
\end{tabular}

$<$ Note $>$ Wald statistics obey $\chi \uparrow 2$ distribution with $\mathrm{DF}=4$.

Critical values are $13.280(1 \%$ level, $* * *), 9.490(5 \%, * *)$ and 7.780 (10\% level, $*$ ). 
Table 5a. Contribution of the public investment (G1) shock to variance of each stock price in 1991:Q1-2007:Q4 (unit: \%)

\begin{tabular}{|c|c|c|c|c|c|c|c|c|c|c|}
\hline Period & Aggregate & Agriculture & Mining & Construction & Food & Fiber & Pulp & Chemical & Petro & Rubber \\
\hline 1 & 2.89 & 2.18 & 1.94 & 2 & 2.23 & 2.55 & 2.03 & 2.58 & 2.22 & 2.12 \\
\hline 4 & 5.07 & 4.04 & 3.49 & 3.82 & 4.15 & 4.61 & 3.71 & 4.55 & 4.03 & 3.62 \\
\hline 20 & 4.55 & 4.39 & 3.67 & 3.76 & 4.25 & 4.84 & 3.92 & 4.85 & 4.21 & 4.2 \\
\hline Period & Glass & Steel & Non-steel & Metal & Machine & $\begin{array}{l}\text { Electrical } \\
\text { equipment }\end{array}$ & $\begin{array}{c}\text { Transportation } \\
\text { machine }\end{array}$ & $\begin{array}{c}\text { Precision } \\
\text { machine }\end{array}$ & Other machine & Commerce \\
\hline 1 & 2.61 & 2.32 & 2.55 & 2.31 & 2.72 & 2.37 & 2.5 & 2.39 & 2.34 & 2.6 \\
\hline 4 & 4.57 & 4.17 & 4.43 & 4.11 & 4.66 & 3.7 & 4.16 & 3.78 & 3.89 & 4.46 \\
\hline 10 & 4.46 & 3.93 & 4.19 & 4.16 & 4.61 & 3.52 & 3.97 & 3.87 & 3.89 & 4.03 \\
\hline 20 & 4.97 & 4.23 & 4.53 & 4.79 & 5.21 & 3.79 & 4.32 & 4.47 & 4.41 & 4.14 \\
\hline Period & Finance & Real estate & Land transport & Shipping & Air transport & Warehousing & Information & Utility & Service & \\
\hline 1 & 2.36 & 2.2 & 1.93 & 2.19 & 1.88 & 2.02 & 1.95 & 1.28 & 2.44 & \\
\hline 10 & 3.65 & 3.66 & 3.26 & 3.79 & 3.27 & 3.73 & 2.65 & 2.02 & 3.77 & \\
\hline 20 & 3.46 & 3.69 & 3.21 & 4.16 & 3.55 & 4.12 & 2.39 & 1.73 & 3.87 & \\
\hline
\end{tabular}


Table 5b. Contribution of the public investment (G2) shock to variance of each stock price in 1991:Q1-2007:Q4 (unit: \%)

\begin{tabular}{|c|c|c|c|c|c|c|c|c|c|c|}
\hline Period & Aggregate & Agriculture & Mining & Construction & Food & Fiber & Pulp & Chemical & Petro & Rubber \\
\hline 1 & 2.03 & 1.58 & 1.39 & 1.41 & 1.59 & 1.83 & 1.46 & 1.86 & 1.6 & 1.56 \\
\hline 4 & 5.55 & 4.34 & 3.78 & 4.12 & 4.48 & 4.98 & 4 & 4.92 & 4.35 & 3.91 \\
\hline 10 & 5.13 & 4.34 & 3.72 & 3.94 & 4.36 & 4.91 & 3.95 & 4.89 & 4.28 & 4.04 \\
\hline 20 & 5.22 & 4.83 & 4.07 & 4.19 & 4.72 & 5.37 & 4.34 & 5.39 & 4.68 & 4.62 \\
\hline Period & Glass & Steel & Non-steel & Metal & Machine & $\begin{array}{c}\text { Electrical } \\
\text { equipment }\end{array}$ & $\begin{array}{c}\text { Transportation } \\
\text { machine }\end{array}$ & $\begin{array}{c}\text { Precision } \\
\text { machine }\end{array}$ & $\begin{array}{c}\text { Other machine } \\
\text { Commerce }\end{array}$ \\
\hline 1 & 1.9 & 1.66 & 1.83 & 1.7 & 1.99 & 1.72 & 1.81 & 1.78 & 1.72 & 1.84 \\
\hline 4 & 4.95 & 4.52 & 4.82 & 4.42 & 5.05 & 4.08 & 4.54 & 4.12 & 4.23 & 4.88 \\
\hline 10 & 4.96 & 4.39 & 4.7 & 4.57 & 5.13 & 4 & 4.47 & 4.31 & 4.33 & 4.58 \\
\hline 20 & 5.51 & 4.73 & 5.08 & 5.24 & 5.76 & 4.31 & 4.85 & 4.95 & 4.89 & 4.73 \\
\hline Period & Finance & Real estate & Land transport & Shipping & Air transport & Warehousing & Information & Utility & Service \\
\hline 1 & 1.61 & 1.53 & 1.32 & 1.58 & 1.34 & 1.45 & 1.34 & 0.84 & 1.73 \\
\hline 4 & 4.75 & 4.5 & 4.08 & 4.28 & 3.72 & 4.17 & 3.59 & 2.82 & 4.56 \\
\hline 10 & 4.19 & 4.13 & 3.68 & 4.22 & 3.63 & 4.11 & 3.11 & 2.33 & 4.29 \\
\hline 20 & 4.04 & 4.2 & 3.66 & 4.61 & 3.94 & 4.53 & 2.89 & 2.06 & 4.43 \\
\hline
\end{tabular}


Table 5c. Contribution of the public investment (G3a) shock to variance of each stock price in 1991:Q1-2007:Q4 (unit: \%)

\begin{tabular}{|c|c|c|c|c|c|c|c|c|c|c|c|}
\hline Period & Aggregate & Agriculture & Mining & Construction & Food & Fiber & Pulp & Chemical & Petro & Rubber \\
\hline 1 & 2.04 & 1.59 & 1.4 & 1.42 & 1.6 & 1.84 & 1.47 & 1.87 & 1.61 \\
\hline 4 & 5.58 & 4.36 & 3.79 & 4.14 & 4.5 & 5.01 & 4.02 & 4.95 & 4.38 & 3.94 \\
\hline 10 & 5.16 & 4.36 & 3.74 & 3.96 & 4.38 & 4.93 & 3.97 & 4.92 & 4.3 & 4.06 \\
\hline 20 & 5.25 & 4.85 & 4.09 & 4.2 & 4.74 & 5.39 & 4.36 & 5.41 & 4.7 & 4.64 \\
\hline Period & Glass & Steel & Non-steel & Metal & Machine & $\begin{array}{c}\text { Electrical } \\
\text { equipment }\end{array}$ & $\begin{array}{c}\text { Transportation } \\
\text { machine }\end{array}$ & $\begin{array}{c}\text { Precision } \\
\text { machine }\end{array}$ & $\begin{array}{c}\text { Other machine } \\
\text { Commerce }\end{array}$ \\
\hline 1 & 1.91 & 1.67 & 1.84 & 1.71 & 2 & 1.73 & 1.82 & 1.79 & 1.73 & 1.85 \\
\hline 4 & 4.98 & 4.55 & 4.85 & 4.44 & 5.08 & 4.11 & 4.57 & 4.15 & 4.25 & 4.91 \\
\hline 10 & 4.99 & 4.41 & 4.73 & 4.59 & 5.15 & 4.03 & 4.5 & 4.34 & 4.35 & 4.61 \\
\hline 20 & 5.53 & 4.75 & 5.1 & 5.26 & 5.79 & 4.34 & 4.88 & 4.97 & 4.91 & 4.76 \\
\hline Period & Finance & Real estate & Land transport & Shipping & Air transport & Warehousing & Information & Utility & Service & & \\
\hline 1 & 1.62 & 1.53 & 1.33 & 1.59 & 1.35 & 1.46 & 1.35 & 0.84 & 1.74 \\
\hline 4 & 4.77 & 4.52 & 4.1 & 4.3 & 3.74 & 4.19 & 3.61 & 2.83 & 4.59 \\
\hline 10 & 4.21 & 4.15 & 3.69 & 4.24 & 3.65 & 4.13 & 3.13 & 2.34 & 4.31 \\
\hline 20 & 4.06 & 4.22 & 3.68 & 4.63 & 3.96 & 4.55 & 2.91 & 2.08 & 4.46 \\
\hline
\end{tabular}


Table 5d. Contribution of the public investment (G3b) shock to variance of each stock price in 1991:Q1-2007:Q4 (unit: \%)

\begin{tabular}{|c|c|c|c|c|c|c|c|c|c|c|c|}
\hline Period & Aggregate & Agriculture & Mining & Construction & Food & Fiber & Pulp & Chemical & Petro & Rubber \\
\hline 1 & 2.11 & 1.64 & 1.45 & 1.47 & 1.65 & 1.9 & 1.52 & 1.93 & 1.66 & 1.62 \\
\hline 4 & 5.58 & 4.39 & 3.81 & 4.17 & 4.52 & 5.02 & 4.03 & 4.96 & 4.39 & 3.94 \\
\hline 10 & 5.14 & 4.37 & 3.74 & 3.97 & 4.39 & 4.93 & 3.98 & 4.91 & 4.31 & 4.06 \\
\hline 20 & 5.23 & 4.86 & 4.09 & 4.22 & 4.76 & 5.4 & 4.37 & 5.41 & 4.7 & 4.63 \\
\hline Period & Glass & Steel & Non-steel & Metal & Machine & $\begin{array}{c}\text { Electrical } \\
\text { equipment }\end{array}$ & $\begin{array}{c}\text { Transportation } \\
\text { machine }\end{array}$ & $\begin{array}{c}\text { Precision } \\
\text { machine }\end{array}$ & $\begin{array}{c}\text { Other machine } \\
\text { Commerce }\end{array}$ \\
\hline 1 & 1.97 & 1.72 & 1.9 & 1.76 & 2.06 & 1.78 & 1.88 & 1.84 & 1.78 & 1.91 \\
\hline 4 & 4.98 & 4.56 & 4.85 & 4.46 & 5.08 & 4.08 & 4.55 & 4.13 & 4.25 & 4.9 \\
\hline 10 & 4.98 & 4.41 & 4.72 & 4.59 & 5.14 & 3.99 & 4.47 & 4.31 & 4.33 & 4.59 \\
\hline 20 & 5.53 & 4.75 & 5.09 & 5.26 & 5.78 & 4.3 & 4.86 & 4.94 & 4.9 & 4.74 \\
\hline Period & Finance & Real estate & Land transport & Shipping & Air transport & Warehousing & Information & Utility & Service & \\
\hline 1 & 1.68 & 1.59 & 1.38 & 1.64 & 1.39 & 1.51 & 1.39 & 0.87 & 1.79 \\
\hline 4 & 4.78 & 4.54 & 4.12 & 4.31 & 3.75 & 4.21 & 3.59 & 2.84 & 4.58 \\
\hline 10 & 4.21 & 4.16 & 3.71 & 4.24 & 3.66 & 4.15 & 3.1 & 2.35 & 4.29 \\
\hline 20 & 4.06 & 4.23 & 3.69 & 4.64 & 3.97 & 4.57 & 2.88 & 2.09 & 4.44 \\
\hline
\end{tabular}


Figure A.1. Source of the data on TFP

\begin{tabular}{|c|c|}
\hline Data & Source \\
\hline $\begin{array}{l}\text { Real GDP (chained), } \\
\text { Compensation of } \\
\text { Employees, and Total } \\
\text { Income }\end{array}$ & $\begin{array}{l}\text { National Account (93SNA, seasonally } \\
\text { adjusted and reference year 2000) in } \\
\text { the Annual Report on the National } \\
\text { Account, Cabinet Office }\end{array}$ \\
\hline Capital Stock & $\begin{array}{l}\text { Capital Stock on Private Sector } \\
\text { (93SNA) with adjustment for } \\
\text { privatization, Cabinet Office }\end{array}$ \\
\hline Working Population & $\begin{array}{l}\text { Labor Force Survey (for all industries), } \\
\text { Ministry of Internal Affairs and } \\
\text { Communication }\end{array}$ \\
\hline Working hours & $\begin{array}{l}\text { Monthly Labour Survey (All industries, } \\
\text { companies with more than } 30 \\
\text { employees), Ministry of Health, Labour } \\
\text { and Welfare }\end{array}$ \\
\hline Business Survey Index & $\begin{array}{l}\text { Business Survey Index for Capital } \\
\text { Investment (Large Company, Non- } \\
\text { manufacturing), Ministry of Finance }\end{array}$ \\
\hline $\begin{array}{l}\text { Operating Ratio of } \\
\text { Capital }\end{array}$ & $\begin{array}{l}\text { Indices of Operating Ratio of } \\
\text { Manufacturing }(1995=100) \text {, Ministry of } \\
\text { Economics, Trade and Industry }\end{array}$ \\
\hline $\begin{array}{l}\text { Maximum Working } \\
\text { Population }\end{array}$ & $\begin{array}{l}\text { We separate the population into two } \\
\text { categories: (1) from } 15 \text { to } 64 \text { years old } \\
\text { and (2) more than } 65 \text { years old. Then, } \\
\text { we adjust the linear trend of the } \\
\text { working population to the peak of } \\
\text { original data for each category, and we } \\
\text { total these two adjusted linear trends. }\end{array}$ \\
\hline Maximum Working hours & $\begin{array}{l}\text { (In designed hours) We separate three } \\
\text { samples: (1)1978:1-1987:4 (2)1988:1- } \\
\text { 1993:4 (3) 1994:1-1997:3. And for } \\
\text { each sample, we calculate the linear } \\
\text { trend and adjust it to the peak of the } \\
\text { original data. } \\
\text { (Out of designed hours) We adjust the } \\
\text { linear trend of working hours to the } \\
\text { peak of the original data. } \\
\text { Then, we total these two adjusted } \\
\text { linear trends. }\end{array}$ \\
\hline
\end{tabular}

